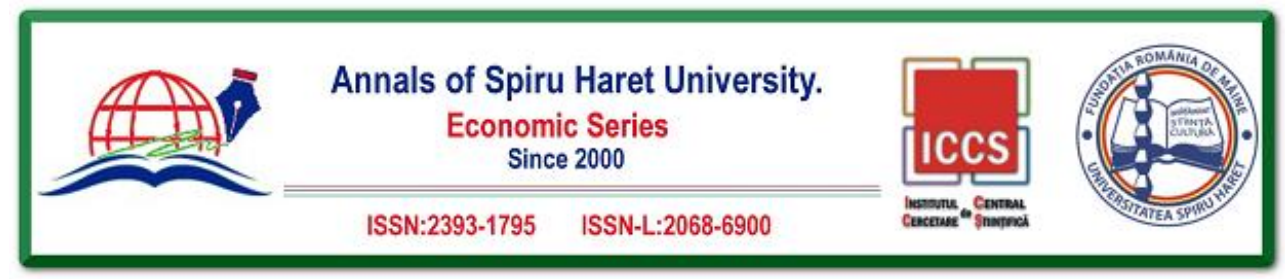

Issue 3/2018

\title{
LAND USE, INTERNAL MOBILITY AND EXTERNAL IMMIGRATION IN ITALY
}

\author{
Giuseppe CELI' ${ }^{1}$, Domenico VITI ${ }^{2}$ \\ ${ }^{1}$ Department of Economics, University of Foggia, Largo Papa Giovanni \\ Paolo II, 1, 71100, Foggia, Italy, Telephone: 0039.0881.781815, \\ Email: giuseppe.celi@unifg.it \\ ${ }^{2}$ Department of Law, University of Foggia, Largo Papa Giovanni Paolo \\ II, 1, 71100, Foggia, Italy, Telephone: 0039.0881.582247, \\ Email:domenico.viti@unifg.it
}

How to cite: CELI, G. \& VITI, D. (2018). "Land Use, Internal Mobility and External Immigration in Italy," Annals of Spiru Haret University. Economic Series, 18(3), 23-42, doi: https://doi.org/10.26458/1832

\begin{abstract}
After the Second World War, the economic development of Italy has profoundly changed the use of land. The paper investigates economic and regulatory implications of land withdrawal in Italy and the nexus with internal and external migration. The dualistic character of Italian economic development induced, especially in the 1950s and 1960s, huge migration flows from southern regions to the North, with strong repercussions in terms of abandonment of farmland and urban congestion. In recent times, in the light of increasing pressures from globalization, a revival of internal migration flows from the South to the North has occurred in Italy, but with different characteristics and implications with respect to the past. The interaction between internal mobility and external immigration (a new phenomenon for Italy, traditionally an emigration country) entails possible economic contra-indications but also new opportunities for rural development.
\end{abstract}

Keywords: globalization; rural development; human capital; migration. 


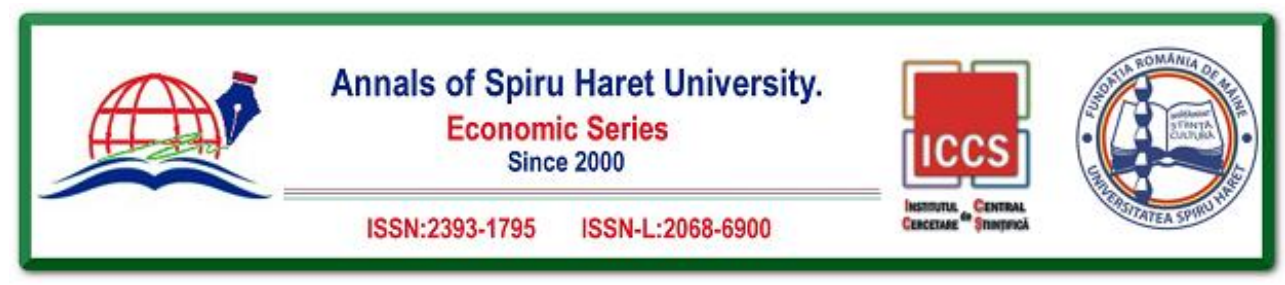

Issue $3 / 2018$

JEL Classification: $\mathrm{R}_{11}, \mathrm{R}_{14}, \mathrm{R}_{23}, \mathrm{~F}_{16}$

\section{Introduction}

Nowadays, especially in developed economies, the transformation of farmland and forests in urban areas implies strong socioeconomic contraindications and costs: a reduction of the soil available for food and timber production; a menace for the survival of local agricultural economies and rural communities; a danger for the quality of the air and, in general, for the provision of ecosystem services; a reduction of open spaces and environmental amenities for residents; an increase in income inequalities among communities, if land conversion goes hand in hand with suburbanization processes [Wu, 2008]. In addition, land use modifications in association with changes in the geographical distribution of economic activities entail cycles of internal migrations of population that crucially retroact on the land use itself.

In the case of Italy, historically, this kind of transformations has involved profound implications for the country's socioeconomic fabric and public welfare. Particularly after the Second World War, the economic development of Italy has deeply changed the use of land. In 1951, the economic structure of the country was essentially based on agriculture, a sector absorbing more than $45 \%$ of employed labour force. Over a time span of 15 years, the share of agricultural in total employment halved and continued to contract over time until reaching only $3.7 \%$ in 2015 . In addition, the dualistic character of Italian economic development induced, especially in the 1950s and 1960s, huge migration flows from southern regions to the North, with strong repercussions in terms of abandonment of farmland and urban congestion. In recent times, a revival of internal migration flows from the South to the North has occurred in Italy (especially in the period 1995-2008), depending on the different degrees of international integration of the two areas of the country: a North able to export and to attract skilled and well educated workers from the South, an area, instead, less integrated in the world economy and still suffering a chronic backwardness with high level of unemployment, growing poverty and social distress. A further important element to be considered in the last decades is the growing number of foreign immigrants arriving in Italy. This new phenomenon for Italy - traditionally, an emigration country - could have interacted with internal mobility itself, in the sense that the availability of cheap foreign workforce could have undermine the incentives for southern firms to invest and innovate, reducing their demand for skilled labour and fuelling human capital outflows from the Mezzogiorno (Southern Italy). However, the other side of the coin of external immigration is that it could represent an important resource to boost rural development in Italy, in the sense that the chronic abandonment of hill and mountain villages by 


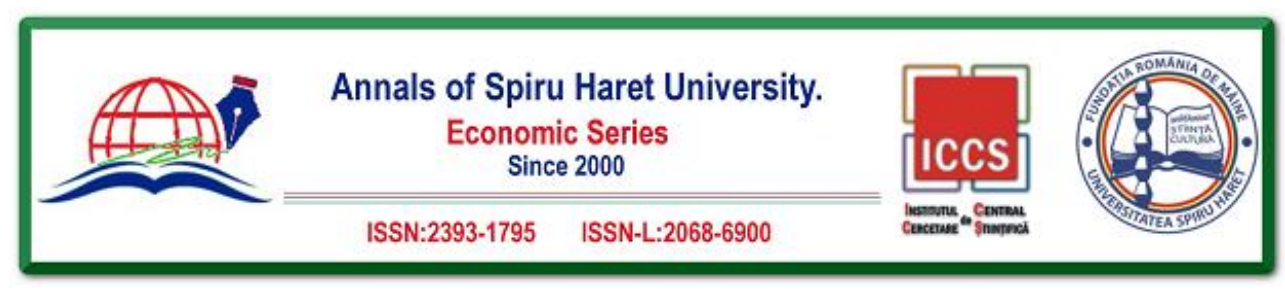

Issue 3/2018

native population could be counterbalanced by inflows of people coming from abroad and eager to create new communities that could revitalise agricultural and rural activities.

Based on this considerations, this contribution explores the links among internationalization processes, internal mobility and external immigration in Italy and how these phenomena retroact on the use of land. The paper is organized as follows. Section 2 focuses on some characteristics of external immigration in Italy and explores the evolution of native internal mobility from the Mezzogiorno to Central and Northern Italy over the last two decades. Section 3 looks at the asymmetric impact of globalization on Italian regions by providing evidence of the different position of the Mezzogiorno in the international division of labour with respect to the Centre-North. Section 4 offers an institutional and legal framework to better interpret the positive potential of the nexus between immigration and inner and mountain rural areas in Italy. Section 5 provides some concluding remarks.

\section{External Immigration and Native Internal Mobility in Italy}

In recent years, studies and economic reports from the main Italian research institutions - such as, inter alia, Bank of Italy and Svimez ${ }^{1}$ - have drawn attention to migration flows which are coming both from abroad to Italy and, internally, from native Italians to different regions of the country. At the same time, the reports have raised the alarm over the widening economic gap between the Italian Mezzogiorno (Southern Italy) and the rest of the country. The interplay between demographic, social and economic factors can be considered as a multilevel ground responsible for these developments, with particular regard to the resurgence of internal migration flows from Southern to Central and Northern Italy. On the one hand, an important element to consider is the population structure by age that in Central and Northern Italian regions has been characterized by a faster pace of population ageing with respect to the Italian Mezzogiorno during the past four decades. This geographical differentiation in population dynamics could have restrained the renewal of labour force through the recruitment of local workers in Central and Northern Italy and, at the same time, encouraged labour mobility from the Mezzogiorno to the rest of the country. On the other hand, being the economic system of the Mezzogiorno less developed in comparison with the Centre-North, a mismatch between the aspirations of highly educated young people in the Mezzogiorno and poor local job opportunities could have stimulated migration outflows from the South. However, as will be shown in section 3,

\footnotetext{
${ }^{1}$ Svimez, Association for industrial development in the Italian Mezzogiorno.
} 


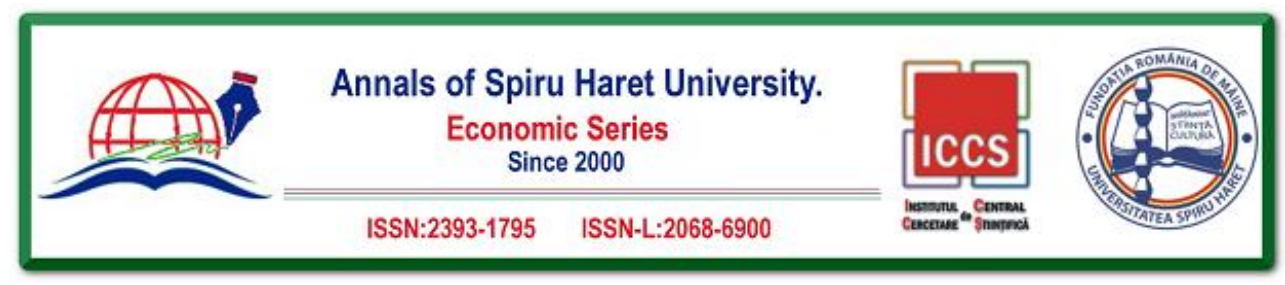

Issue 3/2018

the nexus between the intensification of migration flows and the growing economic distance that separates the Mezzogiorno from Central and Northern Italy can be discerned by examining the processes of international economic integration and their regionally differentiated effects on Italy's productive system.

Before examining the Mezzogiorno's position in the Italian and international economic system, it is useful to look at empirical evidence concerning both migration flows from abroad into Italy and inter-regional flows of native Italians from the Mezzogiorno to Central and Northern Italy.

Data regarding the characteristics of external immigration in Italy before 2008 crisis are reported in Bank of Italy (2009). These data reveal that immigrants - who tend to display higher rates of employment than native Italians - have contributed to sustaining employment rates especially in Central and Northern Italy (C-N, hereafter). Their remuneration is more modest than that of the natives due to their lower educational levels, the concentration of their jobs in the low added-value sectors, and because they perform low-skilled tasks. But one aspect of immigrant characteristics is particularly interesting: foreign-born workers in the Mezzogiorno are less educated than foreign immigrants employed in the C-N. This aspect of regional differentiation in immigrant characteristics reveals that the divergence between Northern and Southern Italy with respect to their productive structures is still crucial in driving the differences in the level of development between the two areas, over and above other important factors - now much emphasized - such as social capital, institutions, etc. ${ }^{2}$

A second piece of evidence (shown in Svimez reports, various years) concerns the dramatic outflow of native Italians from the Mezzogiorno to the C-N: between 1990 and 2009, 2,385,000 individuals left Southern Italy and became resident in Central and Northern Italy (see Fig. 1) ${ }^{3}$. The main area of concern is that the emigrants are mainly individuals with a high degree of education. In recent years, about half of those who moved from the Mezzogiorno to the C-N have a bachelor's degree or high school education. Mocetti and Porello (2010) reported that between 2000 and 2005 the net loss of graduates in the Southern regions, in terms of transfers to the C-N, amounted to 50,000 units, a figure in stark contrast to the

\footnotetext{
${ }^{2}$ Alberto Alesina and Andrea Ichino, for instance, emphasize how much the lack of social capital and civic sense is the main cause of backwardness in the South; they propose four micro-actions for rebuilding social capital in the Mezzogiorno. See Alesina and Ichino (2009).

${ }^{3}$ For a recent long term analysis of internal migration flows in Italy, see Bonifazi et al. (2018). 


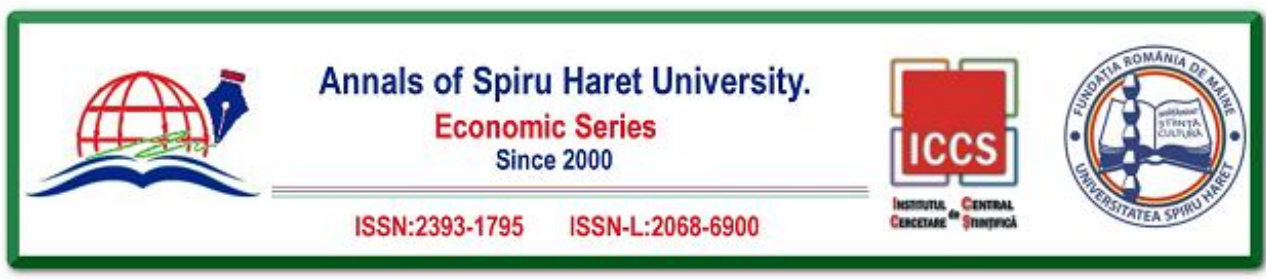

Issue 3/2018

previous decade $(20,000$ units for the entire period of the 1990s). Moreover, it is striking that as much as $40 \%$ of Southern graduates with honours degrees emigrate to the $\mathrm{C}-\mathrm{N}$, because here the remuneration is almost $50 \%$ higher than what they could receive in the South, even allowing for the fact that the labour contracts are less stable [Svimez, 2009] $]^{4}$. The graduates do not represent most of migrants, but the section that grows more: from 17,000 in 2007 to 26,000 in 2012. This means $+50 \%$ in only five years, an impressive figure when you consider that in the South there are fewer graduates than in the C-N [Svimez, 2014]. Therefore, it is the people who represent highly qualified human capital who leave the Southern regions to work in the $\mathrm{C}-\mathrm{N}$, a state of affairs that could compromise long-term growth of the Mezzogiorno ${ }^{5}$.

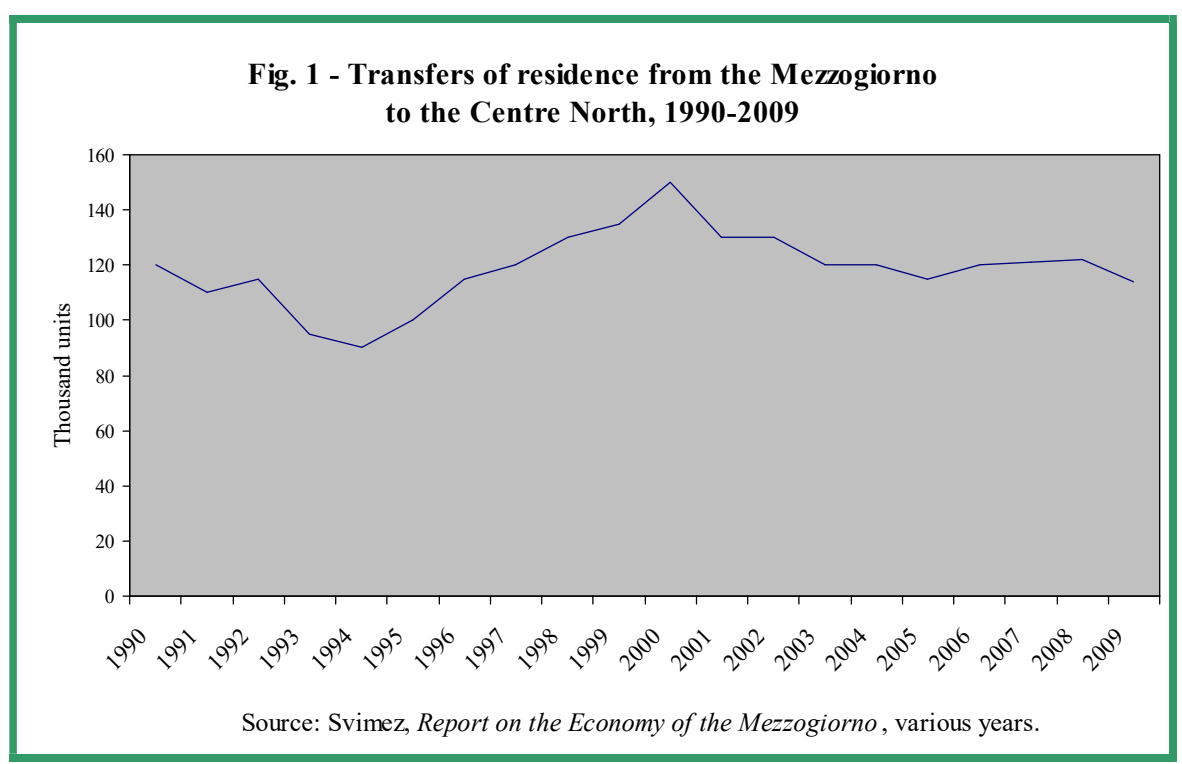

${ }^{4}$ It should be added that the number of people working in the C-N while maintaining official residence in the South has increased substantially in the last decade. In other words, so-called long-distance commuting is on the rise and this phenomenon especially involves highly educated young people and individuals employed in medium and high-skilled jobs.

5 A recent analysis provided by Piras (2016) show that the dramatic outflows of graduates from the Mezzogiorno to the Centre-North is accompanying with emigration of Centre-North graduates to foreign countries. 


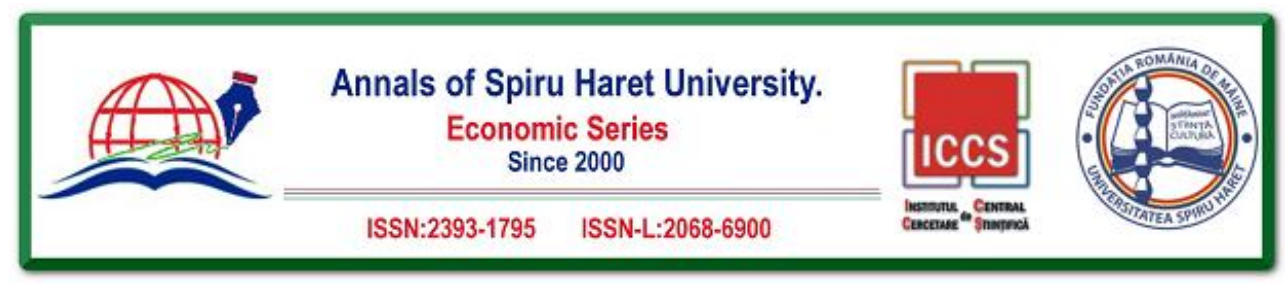

Issue 3/2018

\section{The Asymmetric Impact of Globalization on Italian Regions}

The type of native migrant flows leaving the South and the differences between the C-N and the South in the characteristics of immigrants from abroad are closely related to the evolution of productive specialization that has affected the different areas of the country in the context of international integration processes ${ }^{6}$. This connection becomes clear if we try to build a general interpretive framework on the structural dynamics that have affected the Italian economy in recent years. Over the past 20 years, in Italy as in other advanced countries, there has been an upgrading of the workforce (an increase in the ratio of skilled to unskilled labour) induced by technological change, but also by the processes of international integration with emerging economies ${ }^{7}$. If we look at the factor content of trade flows between advanced countries and emerging markets, we see a higher (lower) skilled/unskilled labour ratio in the export of advanced countries (emerging countries). Therefore, the integration between the two groups of countries has led to a crowding out of unskilled labour in the advanced countries and thus an upgrading of the workforce. This dynamic has definitely affected the regions of northern Italy but much less those

${ }^{6}$ The different impact of globalization on Italian regions can be interpreted through the lens of a core-periphery approach, as in Celi et al. (2018). On the interaction between migration and international trade, see Felbermayr et al. (2015).

7 The literature on the interplay between globalization, technological change and labour market is very copious and varied. For a useful systematization, see the survey of Greenaway and Nelson (2001). Recent analyses on the interaction between international trade, outsourcing and labour market are provided by Antràs et al. (2017), Artuç and McLaren (2015), Autor et al. (2015), Autor et al. (2016), Autor and Salomons (2018), Bloom et al. (2016), Dai and Xu (2017), Dauth et al. (2016), Dix-Carneiro and Kovak (2017), Fajgelbaum and Khandelwal (2016), Hakkala and Huttunen (2016), Hakobyan and McLaren (2016), Helpman (2016), Keller and Utar (2016), Malgouyres (2017), Meschi et al. (2016). A recent strain of literature debates on the impact of automation and technological change on employment, skill composition of jobs and tasks. On this regard, see Arntz et al. (2017), Beaudry et al. (2016), Berger and Frey (2017), Bessen (2016), Brougham and Haar (2018), Charles et al. (2016), Clark (2017), Collard-Wexler and De Loecker (2015), Cortes (2016), Cortes et al. (2016), Dekker et al. (2017), Frey and Osborne (2017), Graetz and Michaels (2017), Maloney and Molina (2016), Mnif (2016), Mokyr et al. (2015), Morikawa (2017), Naastepad and Mulder (2018), Ngai and Pissarides (2017), OECD (2016), OECD (2017), Pierce and Schott (2016), Steward and Stanford (2017), Susskind and Susskind (2016), Ugur and Mitra (2017), Wajcman (2017), World Bank (2016). 


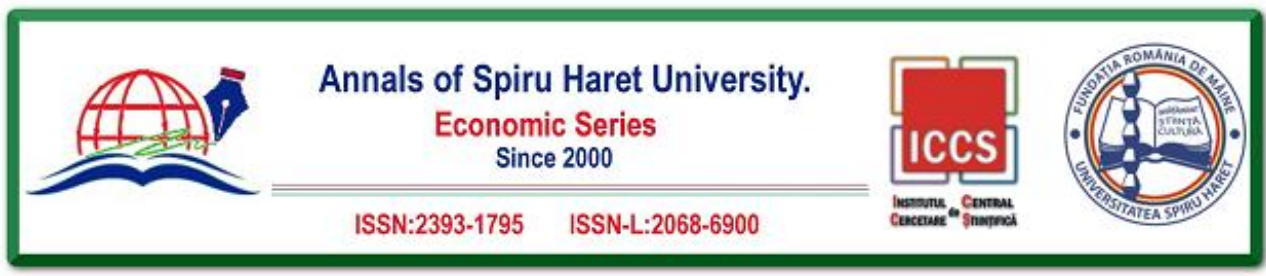

Issue 3/2018

of the South: if we look at the production of the North, these are complementary in terms of factor content with respect to those of emerging countries; whereas, if we look at the goods exported by the southern regions, these are substitutes for imported goods from developing countries (see Fig. 2 and 3$)^{8}$.

Fig 2- Factor content of North Italy trade with eme rging countries

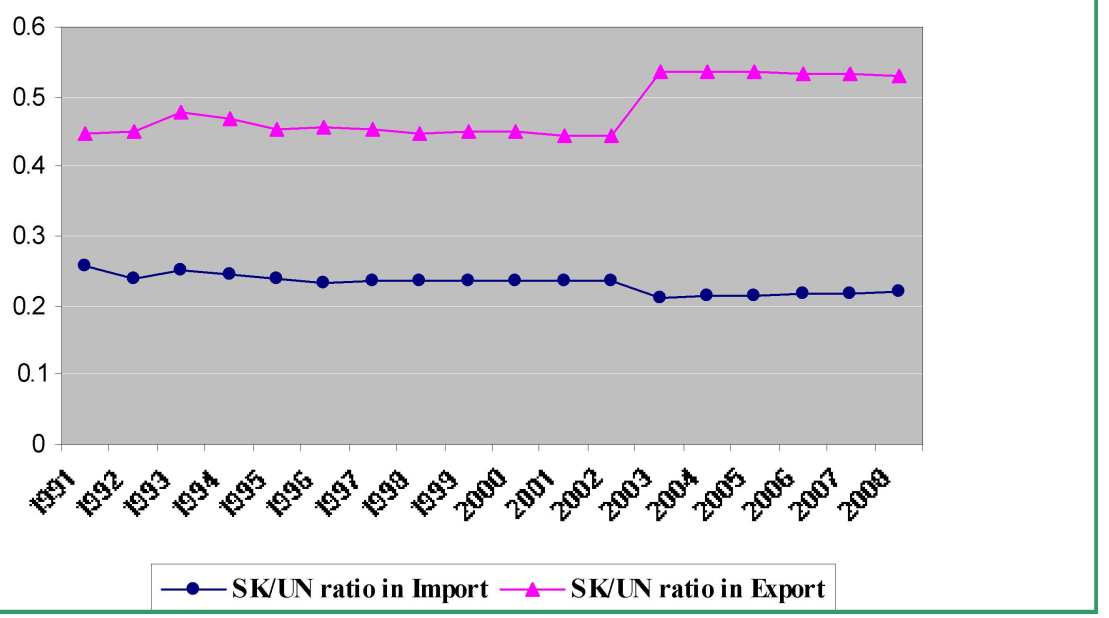

Note: $\mathrm{SK} / \mathrm{UN}$ ratio indicates the ratio of skilled to unskilled labour Source: Celi (2013)

Therefore, the effect of composition and skill upgrading of the workforce, through international trade, would operate in the North but not in the South; that instead would suffer the effects of increased competition outright from emerging

${ }^{8}$ In Fig. 2 and 3, the factor content of exports and imports is expressed in terms of the ratio of skilled (SK) to unskilled labour (UN). The factor content of trade (FCT) is calculated by multiplying the input coefficient matrix (skilled and unskilled labour per unit of value added) by the vector of sectoral exports (or imports). The calculation has been carried out using the following data: i) number of Italian dependent employees by professional qualification, industry and region (source: INPS, Italy's National Social Insurance Agency); ii) regional value added by industry (source: ISTAT, Italy's National Statistics Institute); iii) foreign trade of Italian regions by industry (source: ISTAT). 


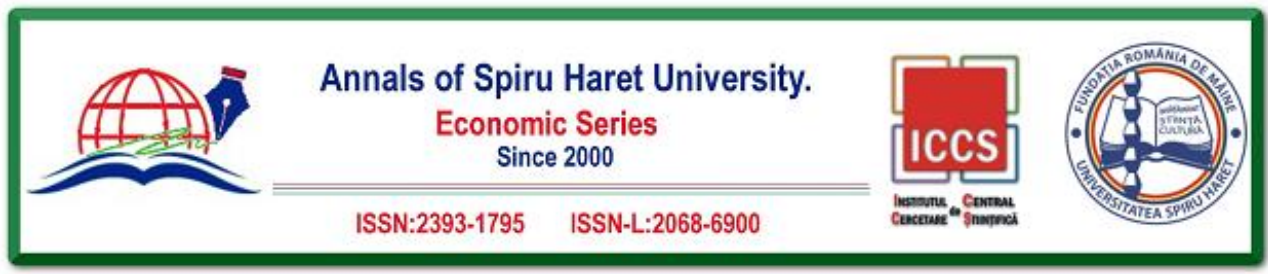

\section{Issue $3 / 2018$}

countries [Celi, 2013]. A recent study by Accetturo, Bugamelli and Lamorgese (2013) achieved results in line with the previous interpretation by reporting that the Italian provinces which exported most in the period 2004-2007 and which were concentrated mainly in the North East of the country were characterized by an increased relative level of education of the workforce employed.

The simple interpretation based on the factor content of trade flows is confirmed by several recent studies that have investigated the new dynamics of internationalization that, since the 1990s of last century, have involved Italian firms. Under the pressure of competition from emerging countries, under the constraint of increased rigidity of the exchange rate and thanks to the opportunity offered by new information technologies, Italian firms have embarked on a major restructuring and reorganization of the division of labour that also imposes forms of internationalization of production.

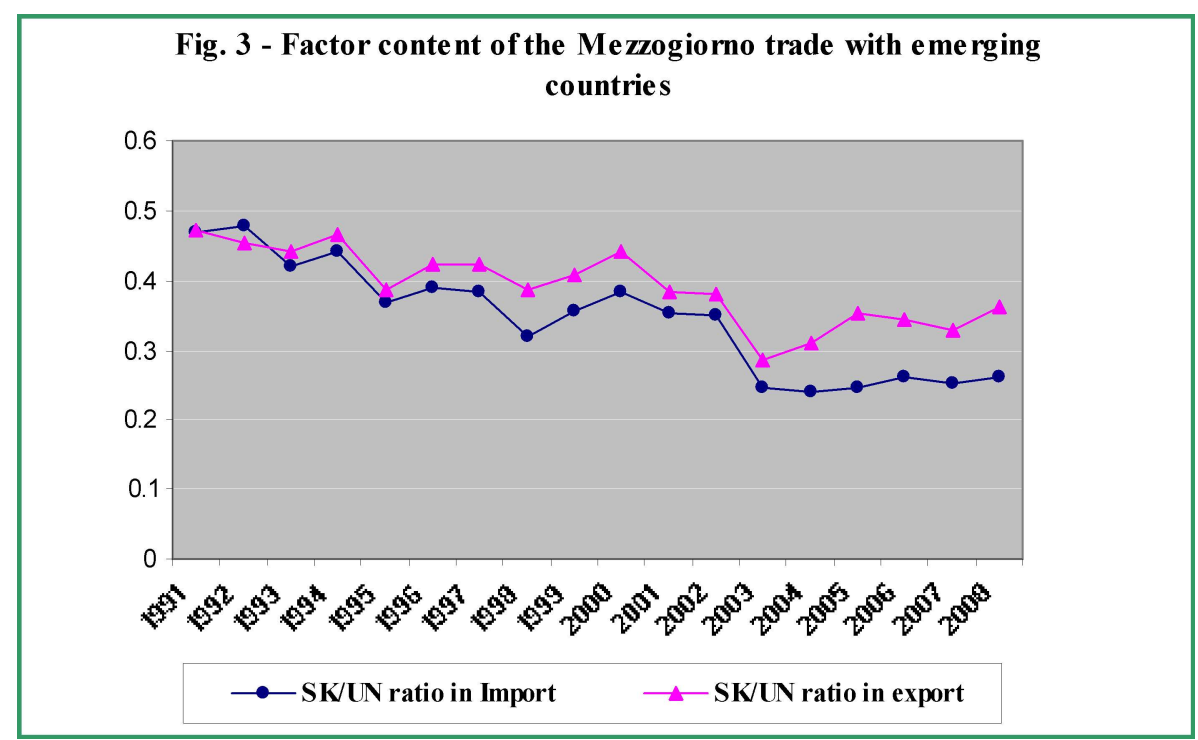

Note: $\mathrm{SK} / \mathrm{UN}$ ratio indicates the ratio of skilled to unskilled labour Source: Celi (2013)

The recent contributions that have assessed, in addition to exports, the impact of outward FDI and international outsourcing on employment and productivity 


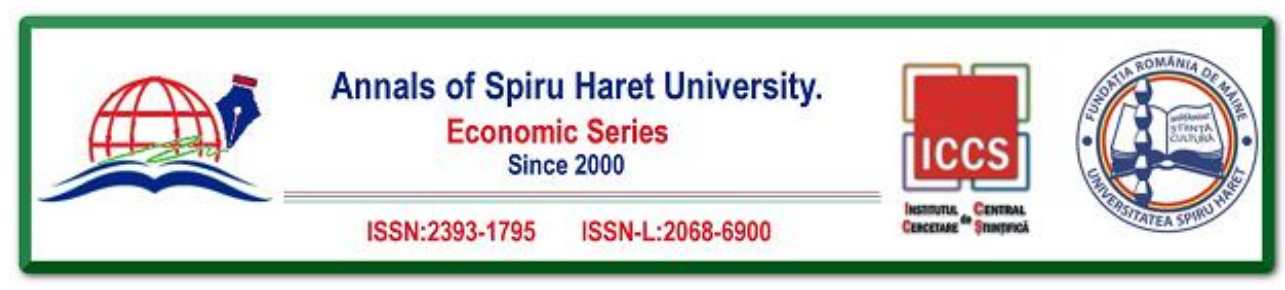

Issue 3/2018

performance of Italian firms, in most cases report an increase in productivity and employment, and a upgrading in the composition of employment ${ }^{9}$. However, the regional dummies included in the regressions indicate that this virtuous link between internationalization and firm performance is especially true for the Centre-North but not for the South. In a recent work in which the territorial dimension is explicitly considered, Giunta et al. (2012) analyze the intensification of subcontracting relationships between Italian enterprises in the 1990s and find that in the case of the South this evolution has not been accompanied, as it has been in the North, by progress in terms of technological innovation, propensity to export, or increasing productivity in subcontractor enterprises: southern firms appear incapable of freeing themselves from the stage of captive supplier and remain in a situation of subordination and vulnerability towards competitive pressures. Even from the recent work undertaken to assess the impact of the recent crisis on Italian production system is not difficult to extrapolate the idea of a radicalization of the production gap also at the regional level. In fact, while firms located in the Centre-North have faced the crisis by implementing strategies of productive restructuring and made efficiency gains through cost reduction, diversification of markets and product quality improvement, southern firms - characterized by their smaller size, limited access to credit, and subcontracting relationship with little bargaining power - confined themselves purely to margin compression ${ }^{10}$.

While analysis of the internationalisation processes involving Italy over the last thirty years suggests economic dynamics favouring progressive divergence between the Centre-North and the Mezzogiorno in their respective production structures, a substantial convergence emerges on turning attention to the educational system. Leaving aside for refined indicators such as dropout rates or PISA or others, one can say that over a long span of time there has been an upward North-South convergence in the education levels of the workforce. Then, the point is that this growth in the education level of the supply of labour in the South has not translated into greater qualification of the labour embodied in the southern productions [Celi \& Sportelli,

9 Helg and Tajoli (2005) reported a positive relationship between international fragmentation of production and relative demand for skilled labour in Italy. D'Attoma and Pacei (2014) found a positive effect of international outsourcing on productivity of Italian firms. However, a more recent analysis provided by Calia and Pacei (2017) finds a significant negative impact of outsourcing on productivity.

${ }^{10}$ See Bronzini et al., (2013); Monteforte and Zevi (2016). 


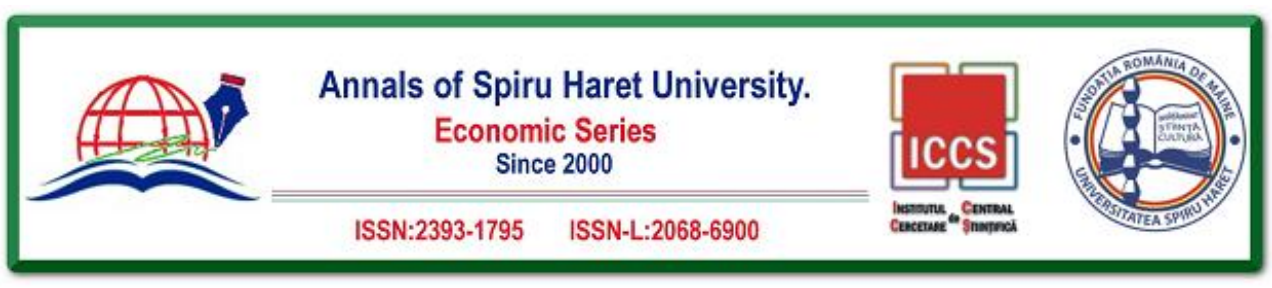

Issue $3 / 2018$

2004]. Therefore, it is reasonable to think that these two dynamics - divergence in production structures due to international integration and convergence upwards in education levels - may have contributed to the increasing migration of skilled labour from the South to the North.

So far, we have built an interpretative framework in which the resurgence of internal migration in Italy in recent years could be imputed to the asymmetric impact of globalization on Italian regions. This explanatory framework helps to better understand the different nature of migration flows with respect to the past. In fact, in contrast with the internal migration that occurred in the period of the Italian economic miracle (in the 1960s), when a great mass of southern workforce with low educational levels flooded to the factories of the "Italian industrial triangle" ${ }^{11}$, as it is called, recent migratory flows from the Mezzogiorno to the rest of the country are accounted for mainly by people with high levels of education. But another really important difference with respect to the past is that, now, native internal migration in Italy goes hand in hand with a parallel increase of external immigration (new phenomenon for Italy that, historically, has been an emigration country). It would be interesting to ascertain if the interaction between native internal migration and external immigration in Italy is a factor that contributes to mitigate North-South divide in Italy or, on the contrary, is a further element enlarging the gap. On the one hand, one would think that the availability of cheap foreign workforce could undermine the incentives for southern firms to invest and innovate, reducing their demand for skilled labour and fuelling human capital outflows from the Mezzogiorno. On the other hand, external immigration might turn out to be an important factor to support and re-launch rural development in Italy. In other words, the dramatic abandonment of hill and mountain villages by native population could be compensate by inflows of foreign immigrants willing to build new communities that could give a new impetus to a reuse of land for agricultural and rural activities. Looking at this second perspective, the next section provides an institutional and legal framework in which the connections between immigration and rural development policies in Italy are explored.

\footnotetext{
${ }^{11}$ Milan, Turin and Genoa are the cities in Italy's North-West forming the vertices of the triangle.
} 


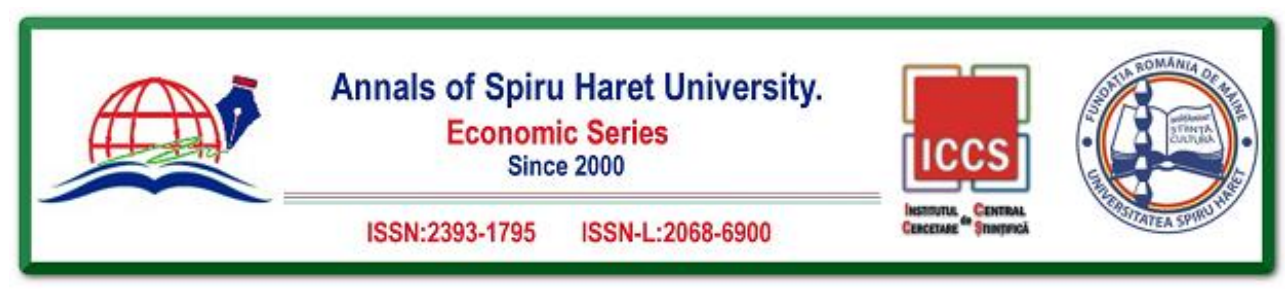

Issue 3/2018

Immigration and Inner and Mountain Rural Areas: Institutional and Legal Framework in Italy

Legislation on immigration and rural development policies have been studied by Italian legal scholarship like two separate bodies of legislation; the demographic and economic patterns of Italy, however, are quickly changing and the lawmakers are facing new challenges. There is not still a strong perception, anyway, of how the two matters can be connected. Many farmers realize that immigrants are saving the Italian agriculture but still legislators are not ready to understand the important, probably unique opportunity that people coming from less developed countries present for the Country. ${ }^{12}$ Immigration should be considered particularly an unexpected possibility for the declining rural and mountain areas; sound economic and demographic reasoning should bring to a correct management of such epochal trend. ${ }^{13}$ Good practices have been experienced in the rich mountain areas of North Italy and a few even in the poorer South, like the famous case of the town of Riace in Calabria. ${ }^{14}$

Italy has presented in the last thirty years a stagnant demographic pattern. The old ideas of the Italian family with many children has long faded away to leave the place with families often with just a child or childless. In rural areas, moreover, there is the additional problem that young generations tend to move to cities to find better job opportunities and many mountain or hill towns have been left just as home of elderly people.

The lack of a common immigration policy by the European Union unfortunately has contributed to make these two topics so distant. While the Common Agricultural Policy has, especially by the so called second pillar, contributed to give help to the drafting of measures to cope with the historical and apparently unrestrainable process towards an almost empty mountain and hilly areas (with the outstanding exception of some parts of the Alps) the legislation on immigration has not fully dealt with the need of many mountain and hill communities to get residents coming from abroad. ${ }^{15}$

${ }^{12}$ It is worth noting, for instance, the role of the Indian Sikh Community in the dairy industry. They are concentrated in the plain and hilly countryside where are produced the famed Parmesan Cheese and Grana Padano, both having the Protected Designation of Origin.

${ }^{13}$ Until the sixties of last the century, Italy was a country of emigrants. Immigration has started in last thirty years to become a full political problem.

${ }^{14}$ For a full evaluation of the policies in Calabria see A. Corrado, M. Dagostino, "I migranti nelle aree interne. Il Caso Calabria," in Agriregioni Europa, n. 45, 2016.

${ }^{15}$ Opinion polls on immigration show that is now considered at the top of the political agenda. 


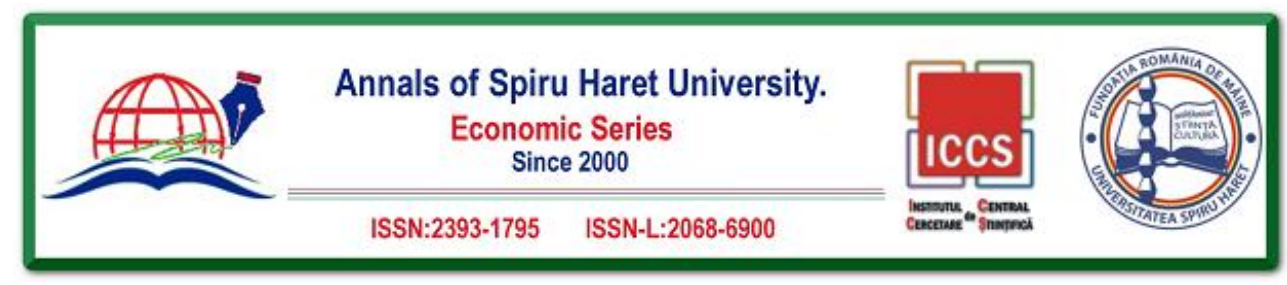

Issue $3 / 2018$

Rural areas in Italy are characterized by a strong presence of mountain landscape. ${ }^{16}$ On the Apennine Mountains, moreover, towns are often at the top of high hills: the reasons are both geographical and historical; the Country has like a backbone the Apennines, which are not far from the sea. In Italy almost $60 \%$ of the national territory should be considered mountain or hilly rural areas but just a little more of $20 \%$ of the population live in this large part of the Country. ${ }^{17}$ This situation creates of course an unbalance between these areas and the part of the Country where most of the economic activities are concentrated. In this vast inner countryside there are no big cities and about $90 \%$ of the municipalities have less than five thousand inhabitants. $^{18}$

Only $40 \%$ of the income is locally produced in mountain and hill areas; it must be considered that this statistical data is even misleading: it is comprehensive of retirement and invalidity pensions. Invalidity pensions has been a sort of misused system of welfare in poor areas, especially in South Italy; while the largest number of retirement pensions is in North Italy in the so called Mezzogiorno, south of Rome, the number of invalidity pensions is twice than in the rich part of the Country.

Rural mountain areas in the South have been beneficiary of some kind of financial protection because of the concentration of retired elderly and invalid people, but huge public expeditions have not solved the backwardness of many mountain town and villages. It is possible therefore to realize a sharp difference between mountain areas in Alps and in the Apennines and different patterns of governance of rural development have been enacted; governance of integration of immigrants also has not been uniform, but it can contribute to give inner and mountain areas a more balanced demographic and economic asset.

${ }^{16}$ There is a fundamental difference between inner and mountain area as rightly pointed by G. Dematteris, "La Montagna nella Strategia per le aree interne 2014-2020," in Agriregioni Europa, n. 9, 2013. Specific policies for mountain areas inside the broader strategy for inner areas should be taken in account. It must be considered, anyway, that in Italy the mountain and hilly areas represent most of the inner areas. For a broad overview of the characteristics of Italian soils, see also Morari (2016) and for the impact of land use changes on hillslope degradation see Brandolini et al. (2018).

${ }^{17}$ A report on mountain areas with statistical data is issued by the Foundation on Mountains.

18 Along the centuries, especially in the long period between the fall of the Roman Empire and the forming of the Italian state, in 1861, living uphill in remote areas was a way to protect themselves both by dangerous invaders coming from the sea and from disease which spread in the plain areas between the mountains and the sea, where swamps were present until the first mid of $20^{\text {th }}$ Century. 


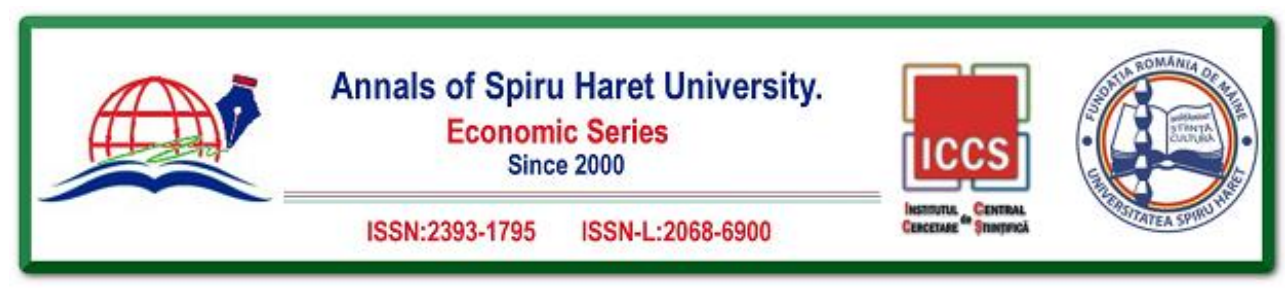

Issue 3/2018

The institutional framework of the country is relevant in understanding different policies in different parts of the country. Friuli, Val d'Aosta and Trentino Alto Adige are, under Constitutional Law, regions which are granted a special statute; that means also that most of taxation remains there. With the broad self-ruling powers of the mentioned Special Statute Regions the three Alpine Regions have developed outstanding rural development programmes, focused especially on the mountain areas. It is noteworthy the case of the area inhabited by the German minority in Italy; in this province the Italian state has maintained the existence of the Maso Chiuso, a family farm comprehensive of land and house. ${ }^{19}$ Good practices of diversification of farming have been first experienced in this tiny part of Italy, starting for instance the farm to become agritourism long before that such activity would been allowed in the rest of the country.

Some links between immigration policies and rural development plans can be found in this part of the country. In the Province of Bolzano, which is meantime a very mountain area and a rich territory where the so called "Contract for integration" operates. It is based on the principle of "supporting in exchange of personal engagements". The province is ready to provide to immigrants a number of services to the ones who willingly decide to attend programmes funded by public institutions. Multiculturalism is encouraged; the immigrants have to learn one of the official languages of the place where they are resident ${ }^{20}$ but the province promotes cultural activities in the language of origin.

The province has taken advantage of the principle of subsidiarity which is affirmed by the Article 118 of the Italian Constitution to provide the immigrants a structured policy of integration which does not want to become a tool of assimilation. ${ }^{21}$

The Region Friuli-Venezia Giulia, bordering Austria and Slovenia, has approved, under the powers given by the Italian Constitution, a specific Regional Legislation, number 31 of 2015, which contemplates the issues of specific plans of integration of the immigrants. Integration is considered an asset for a balanced economic and cultural growth.

${ }^{19}$ Only one child of the family gets the farm by inheritance while the other children have the right to compensation; this system has assured the presence of people also in the areas that otherwise would have been abandoned.

${ }^{20}$ Italian, German, Ladino.

${ }^{21}$ The province has almost $9 \%$ of the population from abroad and it is eager to provide welfare to immigrants who accept the rules. 


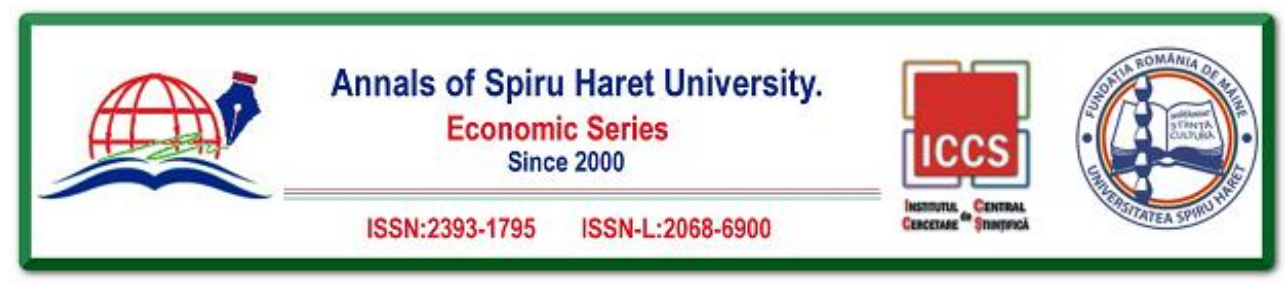

Issue 3/2018

Not in all part of Italy the governance regarding the integration of immigrants should be considered up to such models. The institutional asset in the two other Special Statute regions, overall, has experienced less interesting policies for rural and mountain areas; they are the two Island Sicily and Sardinia. While coastal part of the two islands has acceptable infrastructure and income, inner zones of the two big islands are among the poorest areas in Italy. The other 15 regions are, under Constitutional law, considered under ordinary law so they have much less resources than the five constitutionally privileged regions.

Apennine Mountains are present in all the 15 regions with Ordinary Statute but Veneto (which has Alpine Mountains), Lombardy and Liguria have both Apennine and Alpine hills. Schemes of rural development differ a lot depending on historical and geo-political differences; in most of these Regions integration of immigrants has not found a strong connection with rural development.

The richest region in Italy, Lombardy, has enacted anyway quality policies for its Alps ${ }^{22}$; the same can be affirmed for the Veneto. ${ }^{23}$ There is a significant presence of immigrants in these rich regions but they are mainly in the industrial and plain farming areas and therefore the role of immigrants in inner zone has not yet been structurally dealt.

Under the reform of the Title $\mathrm{V}^{24}$ of the Italian Constitution, the regions have powers related agriculture but very weak possibility of administration about integration of immigration. Regions can anyway adopt both legislative and administrative acts under the subsidiary principle but there is still a reluctant approach to consider immigration as central issue of rural development. ${ }^{25}$

Each Region has a specific Rural Development Programme, which has mainly the function to plan the spending of the financial aids coming from the European

${ }^{22}$ An innovative methodology is presented in the work in progress Montagna Futuro 2018-2023 to define guidelines for planning in mountain areas.

${ }^{23}$ Not by chance, therefore, in 2017 in the traditional list of quality of living drafted by the most prestigious Italian economic newspaper in the first places are all cities at the very bottom of Alps; all the cities which have poor quality of wealth, environmental management, culture and leisure, demography are concentrated in South Italy or in Sicily

${ }^{24}$ The Central State has powers cited by art. 117 of the Constitution, while the others belong to the regions.

25 There has been, related to rural and mountain development, a problem of conflicting rules, because environment has remained under the control of the Central State while agriculture, which has strong relation with the environment, has been assigned to the Regions. 36 


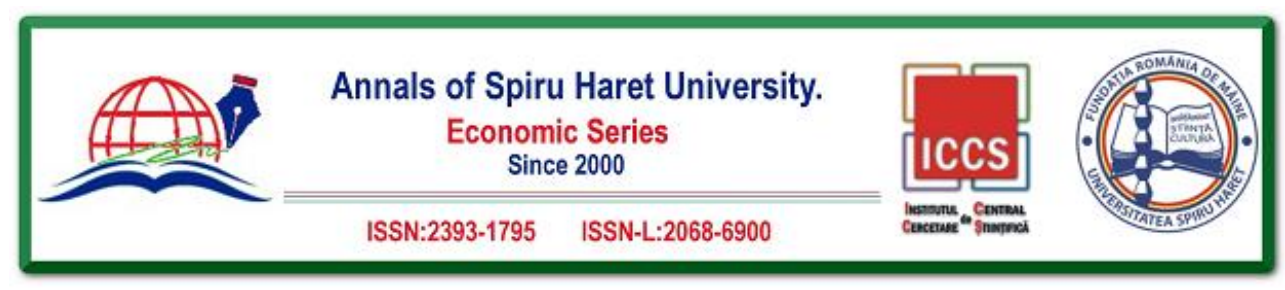

Issue 3/2018

Union. Various regional measures have been scattered to address the problems that are, in a way, the same across the country. Many years of cohesion programmes funded by the European Union do not have much helped to fill the gap especially between Central-Northern and South, especially related to rural and mountain areas. This institutional framework has contributed to the problem of accepting the role of immigration in the growth of the inner areas.

To overcome the evident differences of policies among the regions, the national government has promoted a Strategy for Inner Areas, which is mainly intended to help the regions find the best practices and solutions for growth. ${ }^{26}$ In the Framework Programme Agreements, accepted by the Strategy, good practices of immigrants' integration could be considered in an innovative approach. Regions are anyway the main institutional actors for rural development; the indications of the National Strategy could be therefore assumed more as helpful suggestions than binding rules. National legislation on parks has also an important role in crafting the rural and mountain areas. The Bill n. 394/1991 has contributed to create parks, which can impose their own rules related to development plans. Immigration is becoming a topic also for the governance of parks that under the Constitutional provision related to the environment are regulated by national rules. The National Park of Casentino Forest has framed interesting policies to integrate the large community of immigrants engaged in the logging industry. ${ }^{27}$

An important contribution to the integration could be in the future a correct application of the recent $158 / 2017$ bill which aims to qualify the historical centres of towns below 5,000 inhabitants. The financial resources are limited but can be a further tool for good practices of integration of immigrants in rural areas.

\section{Concluding Remarks}

Looking at the Italian case, this paper has explored the link between the intensification of internal migration, the growth of external immigration and the widening of the productive distance between the South and the Centre-North of Italy. We have argued that an important explanatory framework is the process of

\footnotetext{
${ }^{26}$ See the document "A Strategy for inner Areas in Italy”, by Sabrina Lucatelli, technical meeting at Italian Committee for Inner Areas at the Agency for Territorial Cohesion, Rome, $3^{\text {rd }}$ of July 2014.

${ }^{27}$ In several parts of Italy, immigrants have contributed to save traditional know-how regarding manual labour. In Apulia, most of countryside drywalls are built by Albanian workers.
} 


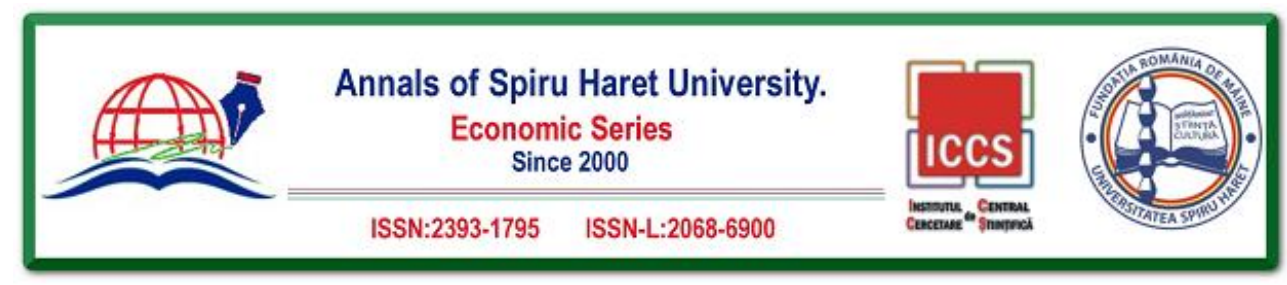

Issue 3/2018

international integration of production that in recent decades have affected in different ways the North and the South of the country. As pointed out in the previous section, a dual dynamic could explain the new features of the territorial mobility in recent years: the North-South production divergence boosted by internationalization processes in the last decades and the long run North-South upward convergence in the education levels of the workforce. We have also remarked that the resurgence of internal mobility has been accompanied by a new phenomenon in Italy, namely the rise of external immigration. The interaction between internal mobility and external immigration could entail negative or positive outcomes for the rebalancing of NorthSouth divide in Italy. In section 4, we assume that foreign immigrants represent an important resource to revitalize Italian inner and mountain rural area and, from this perspective, we explore the institutional and legal framework in which complementarities in legislation can be identified in order to connect immigration and rural development policies.

\section{References}

1. Accetturo, A., Bugamelli, M., \& Lamorgese, A. R. (2013). "Skill upgrading and exports in Italian manufacturing", Temi di discussion (Economic working papers) 919, Bank of Italy, Economic Research and International Relations Area.

2. Acemoglu, D., \& Restrepo, P. (2018). "Low-Skill and High-Skill Automation." Journal of Human Capital, 12(2): 204-232.

3. Antràs, P., Fort, T. C., \& Tintelnot, F. (2017). "The Margins of Global Sourcing: Theory and Evidence from U.S. Firms." American Economic Review, 107(9): 2514-64.

4. Arntz, M., Gregory, T., \& Zierahn, U. (2017). "Revisiting the Risk of Automation." Economics Letters, 159, 157-160.

5. Artuç, E., \& McLaren, J. (2015). “Trade Policy and Wage Inequality: A Structural Analysis with Occupational and Sectoral Mobility.” Journal of International Economics, 97(2): 278294.

6. Autor, D. H., Dorn, D., \& Hanson, G. H. (2015). "Untangling Trade and Technology: Evidence from Local Labour Markets.” Economic Journal, 125(584): 621-646.

7. Autor, D. H., Dorn, D., \& Hanson, G. H. (2016). "The China Shock: Learning From Labour Market Adjustment to Large Changes in Trade." Annual Review of Economics, 8, 205-240.

8. Autor, D. H., \& Salomons, A. (2018). "Is automation labour-displacing? Productivity growth, employment, and the labour share." Brooking Papers on Economic Activity, BPEA Conference Draft, March 8-9.

9. Alesina, A., \& Ichino, A. (2009). "Sud e Isole: far crescere il capitale sociale." Il Sole 24 ore, 22 December. 


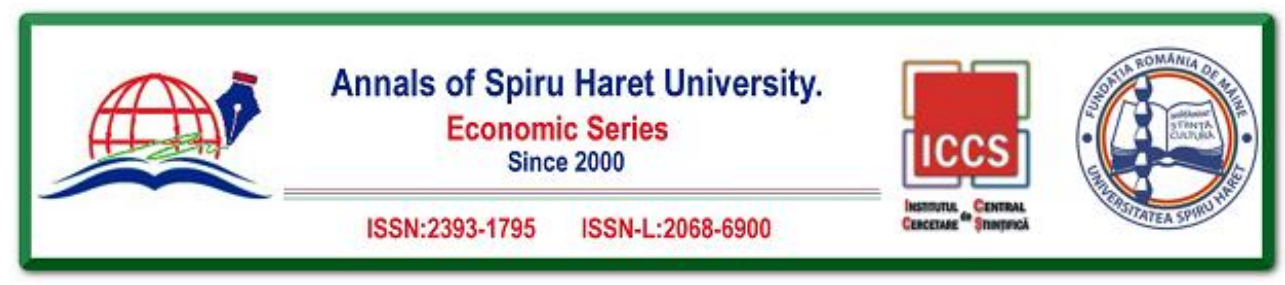

Issue 3/2018

10. Bank of Italy (2009). The Economy of the Italian Regions in the year 2008, No. 61.

11. Beaudry, P., Green, D. A., \& Sand, B. M. (2016). "The Great Reversal in the Demand for Skill and Cognitive Tasks." Journal of Labour Economics, 34(S1), S199-S247.

12. Berger, T., \& Frey, C. B. (2017). "Industrial Renewal in the 21st Century: Evidence from US Cities." Regional Studies, 51(3): 404-413.

13. Bessen, J. E. (2016). "How Computer Automation Affects Occupations: Technology, Jobs, and Skills." Law and Economics Research Paper, No. 15-49, Boston: Boston University School of Law.

14. Bloom, N., Draka, M., \& Van Reenen, J. (2016). "Trade Induced Technical Change? The Impact of Chinese Imports on Innovation, IT and Productivity." The Review of Economic Studies, 83(1): 87-117.

15. Bonifazi, C., Heins, F., \& Tucci, E. "Italy. Internal migration in a low-mobility country", in Champion, T., Cooke, T. \& Shuttleworth, I. (eds.), Internal Migration in the Developed World, London: Routledge, 2018

16. Brandolini, P., Pepe, G., Capolongo, D. et al. (2018), "Hillslope degradation in representative Italian areas: just soil erosion risk or opportunity for development?" Land Degradation \& Development, 1-19, doi: https://doi.org/10.1002/ldr.2999.

17. Bronzini, R., Cannari, L., Staderini, A., \& Santioni, R. "L'industria meridionale e la crisi" (Industry in the south of Italy and the crisis). Questioni di Economia e Finanza, Bank of Italy Occasional Papers, No. 194, 2013.

18. Brougham, D., \& Haar, J. (2018). "Smart Technology, Artificial Intelligence, Robotics, and Algorithms (STARA): Employees' Perceptions of Our Future Workplace." Journal of Management, 24(2): 239-257

19. Calia, P., \& Pacei, S. (2017). "Outsourcing and Firm Performance: Evidence from the Italian Manufacturing Industry." International Journal of Business and Management, 12(1): 87-101.

20. Celi, G., \& Sportelli, M. (2004). "Internazionalizzazione, mercato del lavoro e capitale umano in Italia." Economia e società regionale, 3/2004, 105-128, July.

21. Celi, G. (2013). "Globalization and native internal mobility in a dualistic economy." Économie appliquée, LXVI (4): 57-78.

22. Celi, G., Ginzburg, A., Guarascio, D., \& Simonazzi A. Crisis in the European Monetary Union. A Core-Periphery Perspective. Routledge. London, 2018.

23. Charles, K. K., Hurst, E., \& Notowidigdo, M. J. (2016). "The Masking of the Decline in Manufacturing Employment by the Housing Bubble." Journal of Economic Perspectives, 30(2): 179-200.

24. Clark, J. P. "Creative Destruction: Emerging Technology and the Changing Course of Job Creation", in LaGrandeur, K., \& Hughes, J.J. (eds). Surviving the Machine Age: Intelligent 


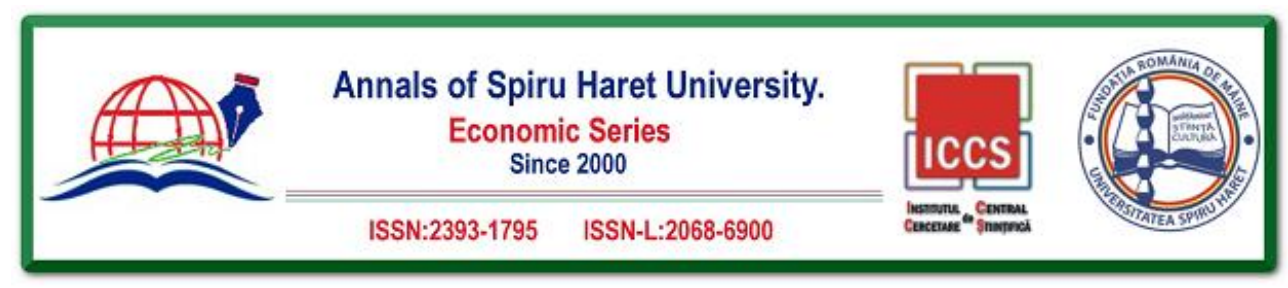

Issue $3 / 2018$

Technology and the Transformation of Human Work. Basingstoke: Palgrave Macmillan, 2017.

25. Collard-Wexler, A., \& De Loecker, J. (2015). "Reallocation and Technology: Evidence from the US Steel Industry." American Economic Review, 105(1): 131-171.

26. Cortes, G. M. (2016). "Where Have the Middle-Wage Workers Gone? A Study of Polarization Using Panel Data." Journal of Labour Economics, 34(1): 63-105.

27. Cortes, G. M., Jaimovich, N., \& Siu, H. E. "Disappearing Routine Jobs: Who, How, and Why?" NBER Working Paper No. 22918. Cambridge, MA: National Bureau of Economic Research (NBER), 2016.

28. D’Attoma, I., \& Pacei, S. (2014). "Offshoring and Firm Performance: Evidence from the Italian Manufacturing Industry." Review of Development Economics, 18(1): 29-44.

29. Dai, M., \& Xu, J. (2017). "The Skill Structure of Export Wage Premium: Evidence from Chinese Matched Employer Employee Data." The World Economy, 40(5): 883-905.

30. Dauth, W., Findeisen, S., \& Suedekum, J. "Adjusting to Globalization - Evidence from Worker-Establishment Matches in Germany." CEPR Discussion Paper No. 11045. London: Centre for Economic Policy Research (CEPR), 2016.

31. Dekker, F., Salomons, A., \& van der Waal, J. (2017). "Fear of Robots at Work: the Role of Economic Self-interest.” Socio-Economic Review, 15(3): 539-562.

32. Dix-Carneiro, R., \& Kovak, B. K. (2017). "Trade Liberalization and Regional Dynamics." American Economic Review, 107(10): 2908-2946.

33. Fajgelbaum, P. D., \& Khandelwal, A. K. (2016). "Measuring the Unequal Gains from Trade." The Quarterly Journal of Economics, 131(3): 1113-1180.

34. Felbermayr, G., Volker, G., \& Kohler, W. "Migration, International Trade, and Capital Formation: Cause or Effect?" in Chiswick, B. \& Miller, P.W. (eds.). Handbook of the Economics of International Migration, Volume 1. Elsevier: Amsterdam, 2015.

35. Frey, C. B., \& Osborne, M. A. (2017). "The Future of Employment: How Susceptible Are Jobs to Computerisation?" Technological Forecasting and Social Change, 114, 254-280.

36. Giunta, A., Nifo, A., \& Scalera, D. (2012), "Subcontracting in Italian Industry. Labour Division, Firm Growth and the North-South Divide." Regional Studies, 46(8): 10671083, December.

37. Graetz, G., \& Michaels, G. "Is Modern Technology Responsible for Jobless Recoveries?" CEP Discussion Paper No. 1461. London: Centre for Economic Performance, 2017.

38. Greenaway, D., \& Nelson, D. "Globalisation and Labour Markets: A Review of the Literature.” in Greenaway D. \& Nelson D. (eds), Globalisation and Labour Markets Vols. I and II, Edward Elgar, 2001.

39. Hakkala, K. N., \& Huttunen, K., "Worker-Level Consequences of Import Shocks", IZA Discussion Paper 10033. Institute for the Study of Labour (IZA), 2016.

40. Hakobyan, S., \& McLaren, J. (2016). "Looking for Local Labour Market Effects of NAFTA." Review of Economics and Statistics, 98(4): 728-741. 


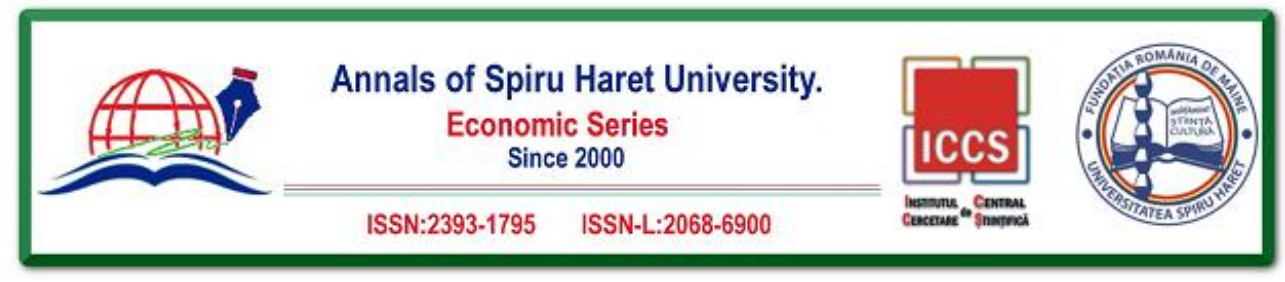

Issue 3/2018

41. Helg, R., \& Tajoli, L. (2005). "Patterns of international fragmentation of production and the relative demand for labour." North American Journal of Economics and Finance, 16, 233-254.

42. Helpman, E., “Globalization and Wage Inequality”, NBER Working Paper No. 22944. Cambridge, MA: National Bureau of Economic Research (NBER), 2016.

43. Keller, W., \& Utar, H. "International Trade and Job Polarization: Evidence at the Worker Level.” NBER Working Paper No 22315, 2016.

44. Malgouyres, C. (2017). "The Impact of Chinese Import Competition on the Local Structure of Employment and Wages: Evidence from France." Journal of Regional Science, 57(3): 411-441.

45. Maloney, W. F., \& Molina, C. "Are Automation and Trade Polarizing Developing Country Labour Markets, Too?" Policy Research Working Paper No. 7922. Washington, D.C.: World Bank, 2016.

46. Meschi, E., Taymaz, E., \& Vivarelli, M. (2016). "Globalization, Technological Change and Labor Demand: a Firm-level Analysis for Turkey." Review of World Economics, 4(152): 655-680.

47. Mnif, S. (2016). "Skill Biased Technological Changes: Case of the MENA Region." Theoretical and Applied Economics, XXIII(3(608)): 339-350.

48. Mocetti, S., \& Porello, C. (2010). "How does immigration affect native internal mobility? New evidence from Italy." Regional Science and Urban Economics, 40(6): 427-439.

49. Mokyr, J., Vickers, C., \& Ziebarth, N. L. (2015). "The History of Technological Anxiety and the Future of Economic Growth: Is this Time Different?" Journal of Economic Perspectives, 29(3): 31-50.

50. Monteforte, L., \& Zevi, G. "An inquiry into manufacturing capacity in Italy after the double-dip recession," Questioni di Economia e Finanza, Bank of Italy Occasional Papers No. 302, 2016.

51. Morari, F. (2016). Review of the book The Soils of Italy, E. Costantini \& C. Dazzi (eds.), Springer: Dordrecht, Heidelberg, New York, London, 2013, Land Degradation \& Development, 27, 1304. doi: 10.1002/Idr.2254.

52. Morikawa, M. (2017). "Firms' Expectations about the Impact of AI and Robotics: Evidence from a Survey." Economic Inquiry, 55(2): 1054-1063.

53. Naastepad \& Mulder (2018). "Robots and us: towards an economics of the "Good Life'." Review of Social Economy, doi: 10.1080/00346764.2018.1432884

54. Ngai \& Pissarides (2017). "Structural change in a multi-sector model of growth." American Economic Review, 97(1): 429-443.

55. OECD (2016), Skills for a Digital World, Paris: OECD

56. OECD (2017), Employment Outlook, 2017, Paris: OECD.

57. Pierce, J. R., \& Schott, P. K. (2016). "The Surprisingly Swift Decline of US Manufacturing Employment." The American Economic Review, 106(7): 1632-1662. 


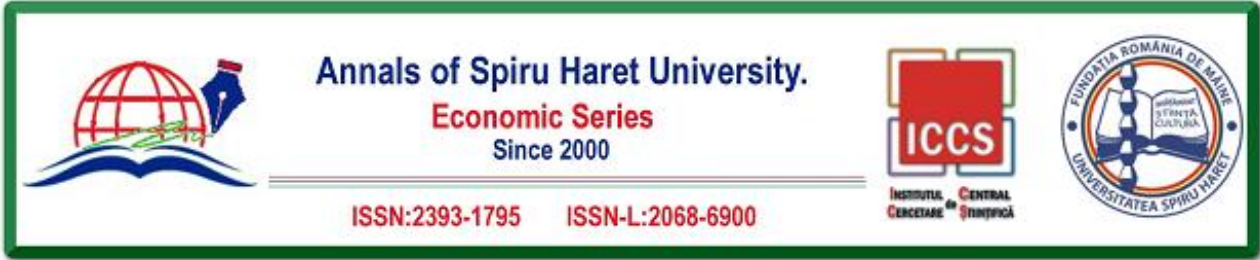

\section{Issue $3 / 2018$}

58. Piras, R. "The internal and international migration flows of Italian college graduates", MPRA Paper 70391. University Library of Munich, Germany, 2016.

59. Steward \& Stanford (2017). "Regulating Work in the Gig Economy: What are the Options?" The Economic and Labour Relations Review, 28(3): 420-437.

60. Susskind, R., \& Susskind, D. The Future of the Professions: How Technology Will Transform the Work of Human Experts. Oxford: Oxford University Press, 2016.

61. Svimez (2009). Report 2009 on the Economy of the Mezzogiorno, Rome, 16 July, http://lnx.svimez.info/it/

62. Svimez (2014). Preview of Report 2014 on the Economy of the Mezzogiorno, Rome, July, http://lnx.svimez.info/it/

63. Ugur, M., \& Mitra, A. (2017). "Technology Adoption and Employment in Less Developed Countries: a Mixed-method Systematic Review." World Development, 96(C): 1-18.

64. Wajcman (2017). "Automation: Is it Really Different This Time?" The British Journal of Sociology, 68(1): 119-127.

65. World Bank. World Development Report 2016: Digital Dividends. Washington, D.C.: World Bank, 2016.

66. Wu, JunJie (2008). "Land use changes: economic, social, and environmental impacts." Choices, 23(4): 6-10. 